\title{
Denitrification Process as an Indicator of Soil Health
}

\section{Praveen Solanki $^{1 *}$, Shiv Singh Meena ${ }^{2}$, Maitreyie Narayan ${ }^{1}$, Hina Khatoon ${ }^{1}$ and Lakshmi Tewari ${ }^{3}$}

\author{
${ }^{1}$ Department of Environmental Science, ${ }^{2}$ Department of Soil Science, ${ }^{3}$ Department of \\ Microbiology, Govind Ballabh Pant University of Agriculture and Technology, \\ Pantnagar (UK)-India \\ *Corresponding author
}

\section{A B S T R A C T}

\begin{tabular}{|l|}
\hline Key w or d s \\
$\begin{array}{l}\text { Soil health, } \\
\text { denitrification, } \\
\text { nitrous oxide, } \\
\text { methemo- } \\
\text { Globinemia. }\end{array}$ \\
\hline Article Info \\
\hline $\begin{array}{l}\text { Accepted: } \\
\text { 25 April 2017 } \\
\text { Available Online: } \\
\text { 10 May 2017 }\end{array}$ \\
\hline \hline
\end{tabular}

Soil health refers to the biological, chemical, and physical features of soil that are essential to long-term, sustainable agricultural productivity with minimal environmental impact. Thus, soil health provides an overall picture of soil functionality. Although it cannot be measured directly, soil health can be inferred by measuring specific soil properties (e.g. organic matter content) and by observing soil status (e.g. fertility). There is also increased interest in studying soil microorganisms in their particular environments, as microbial diversity and biomass are intimately related to soil structure and function. One of the key indicators for soil health is denitrification as it is completely done by soil microorganisms and enzymatic activity. The denitrification process, which reduces nitrate and nitrite to nitric oxide (NO), nitrous oxide (N2O), and dinitrogen (N2), is an important indicator of soil health and $\mathrm{N}$-cycling transformation. It is the only pathway, except for the process of anaerobic ammonium oxidation (Anammox), by which reactive forms of nitrogen $(\mathrm{Nr})$ in terrestrial and aquatic ecosystems are transformed back into inert N2gas.

\section{Introduction}

The denitrification process, which reduces nitrate and nitrite to nitric oxide (NO), nitrous oxide (N2O), and dinitrogen ( 2 2), is an important $\mathrm{N}$-cycling transformation. It is the only pathway, except for the process of anaerobic ammonium oxidation (Anammox), by which reactive forms of nitrogen $(\mathrm{Nr})$ in terrestrial and aquatic ecosystems are transformed back into inert N2 gas (Galloway et al., 2004). (Galloway et al., 2008) indicated that, on a global scale, a strikingly larger amount of data existed about the production of $\mathrm{Nr}$ than about the transformation of $\mathrm{Nr}$ into N2. The identification of key factors controlling denitrification rates and their products is crucial to quantify the effects of human activity on the $\mathrm{N}$ cycle in terrestrial ecosystems and for managing and mitigating the severe environmental consequences associated with $\mathrm{N}$ pollution (Boyer et al., 2006).

Numerous studies have been conducted on denitrification processes in soils, the role of 
these processes in $\mathrm{N}$ loss at the ecosystem level, and the factors influencing denitrification capacity and environmental impacts (Wijler and Delwiche, 1954; Kralova, 1991; Simek et al., 2000; Simek and Cooper, 2002; Hofstra and Bouwman, 2005; Dannenmann et al., 2008). However, denitrification has been primarily measured in soils from temperate zones in industrialized countries (Hofstra and Bouwman 2005) and few measurements quantifying denitrification rates in soils from tropical and subtropical zones have been reported ( $\mathrm{Pu}$ et al., 2001; $\mathrm{Pu}$ et al., 2002). Therefore, the main edaphic variables and mechanisms affecting denitrification rate and its products in the tropical and subtropical zones are not well understood.

Conventional denitrification is a reduction process carried out by diverse bacteria under anoxic conditions and involves a series of reaction from $\mathrm{NO}_{3}-\mathrm{-}$ to dinitrogen gas (N2), catalysed by the nitrate reductase (Nar), nitrite reductase (Nir), nitric oxide reductase (Nor), and nitrous oxide reductase (Nos) (Zumft, 1997).

Briefly, two types of molybdoenzymes catalyzing the first step of the pathway (Figure.1), the reduction of $\mathrm{NO}_{3}$ - to $\mathrm{NO}_{2}$ have been described: a membrane bound (Nar) and a periplasmic (Nap) $\mathrm{NO}_{3}$-reductases. Both types of enzymes can be present in the same strain (WijlerandDelwiche1954). The reduction of solubleNO ${ }_{2}$ - into gaseous nitric oxide (NO), the key step in the denitrification cascade, can be catalyzed by evolutionary unrelated enzymes that are different in terms of structure and of prosthetic metalsa copper (NirK) and a cytochromecd1 (NirS) $\mathrm{NO}_{2-}$ reductase. In contrast to theNO $\mathrm{N}_{3}$-reductases, bacteria carry either the copper or the cd1 $\mathrm{NO}_{2}$-reductase but the two enzymes are functionally equivalent (Kralova, 1991). Reduction of NO into nitrousoxide is also catalyzed by two types of enzymes: one NO reductase receives the electrons from cytochrome c orpseudoazurin (cNor) and the other from aquinol pool (qNor). The last step of the denitrification cascade, reduction of $\mathrm{N}_{2} \mathrm{O}$ into dinitrogen gas, is performed by the multicopper homodimeric $\mathrm{N}_{2} \mathrm{O}$ reductase (NosZ), which is located in the periplasm in Gram-negative bacteria (Simek et al., 2000).

The process of denitrification is therefore generally promoted under anaerobic conditions, high levels of soil $\mathrm{NO}_{3^{-}}$, and a readily available source of carbon.

\section{Materials and Methods}

\section{General requirements}

The general requirements for biological denitrification are:

The presence of bacteria possessing the metabolic capacity;

Suitable electron donors such as organic carbon compounds;

Anaerobic conditions or restricted $\mathrm{O}_{2}$ availability; and

Presence of $\mathrm{N}$-oxides $\left(\mathrm{NO}_{3^{-}}, \mathrm{NO}_{2^{-}}, \mathrm{NO}\right.$, or $\mathrm{N}_{2} \mathrm{O}$ ) as terminal electron acceptors.

\section{Agronomical and environmental importance of denitrification}

Consequences of denitrification for agriculture

Denitrification leads to considerable nitrogen losses in agriculture. The losses tend to increase with fertilization, and between $0 \%$ and $25 \%$ of the applied nitrogen can end up as nitrogen gas or $\mathrm{N} 2 \mathrm{O}$, thus limiting crop production (Aulakh et al., 1992). Studies have shown that up to $340 \mathrm{~kg} \mathrm{~N}$ ha-1 can be lost through denitrification during 1 year under extreme conditions, although values in the range $0-200 \mathrm{~kg} \mathrm{~N}$ ha-1year-1 are more normal (Hofstra and Bouwman, 2005). The values 
obtained depend highly on the methods used to determine denitrification rates. Models have estimated the total annual denitrification for the global agricultural area (excluding leguminous crops) to be $22-87 \mathrm{Tg}$ nitrogen (Hofstra and Bouwman, 2005).

Intensively cultivated soils have higher denitrification activity compared with native non-cultivated soils. Nevertheless, denitrification events in the field occur irregularly in time and space because of weather conditions, heterogeneity of soil conditions, and management practices. The highestrates are often measured in spring and fall, which indicates that soil water status, is a strong controlling factor. Hence, floodirrigated cropping systems are especially prone to denitrification and recovery of fertilized nitrogen is often poor (Aulakh et al., 2001; Mahmood et al., 2000, 2005). To minimize the nitrogen losses, the feasible option is to focus on agricultural practices. After compiling 336 datasets on denitrification measurements, Hofstra and Bouwman (2005) demonstrated that croptype, fertilizer-type, and nitrogen application rate were the most significant managementrelated factors influencing denitrification in agricultural soils. These factors not only affect the nitrogen availability and the form of available nitrogen in soil, but also affect the type and amount of carbon available for denitrification.

\section{Impact of denitrification on the environment}

Denitrification together with nitrification are considered as the primary biological sources of $\mathrm{N}_{2} \mathrm{O}$, which exhibits a global warming potential300 times higher than that of carbon dioxide as defined by the Intergovernmental Panel on Climate Change (IPCC) and contributes up to $6 \%$ of the anthropogenic greenhouse effect (Aulakh et al., 2001). $\mathrm{N}_{2} \mathrm{O}$ also participates in depletion of the stratospheric ozone $\left(\mathrm{O}_{3}\right)$ layer through stratospheric NO production (Galloway et al., 2008). $\mathrm{N}_{2} \mathrm{O}$ emission by denitrification is the net result of the balance between production and reduction of $\mathrm{N}_{2} \mathrm{O}$ by denitrifying bacteria.

Soil ecosystems are the dominant sources of atmospheric $\quad \mathrm{N}_{2} \mathrm{O}$ (Conrad, 1996), contributing to $70 \%$ (10 $\mathrm{Tg}$ year-1) of the total annual global emission with about 6.3 Tg year-1 from agricultural soils, animal production, and other agricultural activities (Mosier et al., 1998). From the preindustrial period to our days, the atmospheric concentration of $\mathrm{N}_{2} \mathrm{O}$ increased from 0.275 to $0.314 \mathrm{ppm}$ with an actual increase rate of $0.3 \%$ per year. This has been attributed to the increased use of nitrogen fertilizers (Skiba et al., 1993). Only between 1960 and 1995, there was a sevenfold increase in fertilization (Tilman et al., 2002). The 1996 IPCC guidelines used a fixed $\mathrm{N}_{2} \mathrm{O}$ emission rate of $1.25 \%$ for all nitrogen applied as fertilizer (Houghton et al., 1996). However, studies suggested $\mathrm{N}_{2} \mathrm{O}$ emissions from agricultural soils might be twice as high as IPCC estimates (Giles, 2005).

\section{Impact of denitrification on human health}

Denitrification is also of interest for nitrogen removal in agricultural drainage and runoff water, groundwater, wastewater, and drinking water, the latter being of a special concern for human health. The removal of nitrogen in the form of ammonia and $\mathrm{NO}_{3^{-}}$is effected through the biological oxidation of nitrogen from ammonia (nitrification) to $\left.\mathrm{NO}_{3}\right\urcorner$, followed by denitrification. Nitrogen gas is then released to the atmosphere and thus removed from the water. High $\mathrm{NO}_{3}$ concentrations in drinking water are toxic, especially to infants under 6 months. However, $\mathrm{NO}_{3}$ - itself does not normally cause health problems unless it is reduced to $\mathrm{NO}_{2-}$ by bacteria that live in the digestive tract. As 
$\mathrm{NO}_{2}$-enters the blood stream, it reacts with hemoglobin to form methemoglobin, and oxygen transportation is blocked. This causes asphyxiation, a disease commonly called blue baby syndrome or methemoglobinemia. Nitrate in groundwater originates primarily from fertilizers, septic systems, and manure storage or application, thus, fertilizer nitrogen that is not taken up by plants, volatilized, denitrified, or carried away by surface run-off leaches to the groundwater in the form of $\mathrm{NO}_{3}{ }^{-}$. The World Health Organization has stipulated a safe upper limit of $45 \mathrm{mg} \mathrm{NO}_{3}-\mathrm{L}$ 1 in drinking water for human consumption.

\section{Who are the denitrifiers?}

\section{Denitrifiers and nitrate reducers}

Many soil prokaryotes can denitrify and exhibit a variety of reduction pathways for nitrogenous oxides. Both cultivationdependent and independent methods showed that the proportion of denitrifiers represent up to $5 \%$ of the total soil microbial community (Henry et al., 2004, 2006; Tiedje, 1988), thus outranking other functional groups involved in the $\mathrm{N}$-cycle such as diazotrophs or nitrifiers.

Some microorganisms produce only nitrogen gas as end denitrification product, while others give a mixture of $\mathrm{N}_{2} \mathrm{O}$ and nitrogen gas, and some only $\mathrm{N}_{2} \mathrm{O}$ (Stouthamer, 1988). In addition, a few microorganisms cannot reduce $\mathrm{NO}_{3}$ and use $\mathrm{NO}_{2-}$ as the first electronacceptor in the denitrification cascade. By contrast, some $\mathrm{NO}_{3-}$ reducingbacteria reduces the produced $\mathrm{NO}_{2-}$ into ammonium and not into NO. The dissimilatory $\mathrm{NO}_{3}$ - reduction into ammonium should be distinguished from denitrification, even though it may produce nitrogenous gases as by products. Therefore, many NO3respiring ammonium-producing isolates have been misidentified as denitrifiers.
Accordingly, different criteria have been proposed to identify true denitrifiers and to distinguish them from the $\mathrm{NO}_{3}$-respiring, ammonium-producing bacteria (Mahne and Tiedje, 1995): (1) $\mathrm{N}_{2} \mathrm{O}$ and/or nitrogen gas must be the major end product of $\mathrm{NO}_{3}-$ or $\mathrm{NO}_{2}$ - reduction; and (2) this reduction must be coupled to an increased in growth yield increase that is greater than when $\mathrm{NO}_{3}$-or $\mathrm{NO}_{2}$ - simply served as an electron sink. Using these criteria, it is also possible to distinguish bacteria possessing only the NO reductase as a protection against exogenous or endogenous nitrosative stress (Philippot, 2005).

\section{Denitrifying populations}

More than 60 genera of denitrifying microorganisms have been identified including archeae and fungi. Consequently, the distribution of the denitrification trait among microorganisms cannot be predicted simply by the taxonomical affiliation. In addition, while distantly related microorganisms can denitrify, closely related strains can exhibit different respiratory pathways. For example, analysis of the ability to use $\mathrm{NO}_{3}$ - as alternative electron acceptor among a collection of fluorescent pseudomonads showed that strains were either denitrifiers, $\mathrm{NO}_{3}$ - reducers, or not capable to respire $\mathrm{NO}_{3-}$ (Clays-Josser and et al., 1995). Among the phygenetically diverse group of denitrifiers, it is interesting that several bacteria are also involved in other steps of the nitrogen cycle, such as nitrification or nitrogen fixation. Thus, ammonia-oxidizing strains belonging to either the Nitrosospira or Nitrosomonas genus have been shown to be capable to denitrify (Shaw et al., 2006). It is also worth to note that the newly discovered group of ammonia oxidizers within the chrenoarcheota, possess the nirK gene encoding the denitrification $\mathrm{NO}_{2}$-reductase (Treush et al., 2005), which suggests that they can perform at least one step of the 
denitrification pathway. Similarly, many nitrogen-fixing rhizobia can denitrify (Daniel et al., 1980, 1982; O'Hara and Daniel, 1985). Eventhough the diversity of denitrifiers is very high, it is likely that several yet unknown microorganisms in nature contribute to the overall denitrification. As an example, Risgaard-Petersen et al., (2006) demonstrated that abenthic foraminifer Globobulimina pseudospinescens accumulates intracellular $\mathrm{NO}_{3}{ }^{-}$stores, which can be respired to dinitrogen gas.

Assessing denitrifiers density, diversity and activity

\section{Measuring denitrification and $\mathrm{N}_{2} \mathrm{O}$ emissions}

Since denitrification is responsible for the loss of available $\mathrm{NO}_{3}$ - for plants, many methods have been developed to estimate denitrification rates in soils. The most basic approach calculates denitrification losses from the nitrogen balance budget. However, other processes such as leaching can lead to NO3- losses, which result in an overestimation of denitrification. An alternative approach is based on the determination of the amount of $\mathrm{N}_{2} \mathrm{O}$ and/or dinitrogen gas emitted by denitrification using various methods described in the following sections.

\section{Acetylene inhibition method}

In this approach, acetylene $\left(\mathrm{C}_{2} \mathrm{H}_{2}\right)$ is used to inhibit $\mathrm{N}_{2} \mathrm{O}$ reduction so that total denitrification losses $\left(\mathrm{N}_{2}+\mathrm{N}_{2} \mathrm{O}\right)$ can be measured as $\mathrm{N}_{2} \mathrm{O}$. The blockage of $\mathrm{N}_{2} \mathrm{O}$ reduction in soil is obtained in an atmosphere containing $0.1-10 \%(\mathrm{v} / \mathrm{v}) \mathrm{C}_{2} \mathrm{H}_{2}$. This method developed independently by Balderston et al., (1976) and Yoshinari et al., (1977) has been a revolutionary key step in estimating denitrification rates and has paved the way for hundreds of studies measuring denitrification rates in situ (Stevens and Laughlin, 1998; Tiedje et al., 1989). The $\mathrm{C}_{2} \mathrm{H}_{2}$ inhibition method has been applied to soil slurries and cores (Ryden et al., 1987), as well as in field measurements using closed chambers (Ryden and Dawson, 1982). For the latter, chambers are placed on the soil surface and $\mathrm{C}_{2} \mathrm{H}_{2}$ is injected, which results in the accumulation of $\mathrm{N}_{2} \mathrm{O}$ in the headspace of the chamber.

The production of $\mathrm{N}_{2} \mathrm{O}$ is estimated by analyzing gas samples from the headspace with a gas chromatograph, preferably equipped with an electron capture detector. The method has some limitations related to the diffusion of $\mathrm{C}_{2} \mathrm{H}_{2}$ in soil, $\mathrm{C}_{2} \mathrm{H}_{2}$ degradation by bacteria, and inhibition of other processes, for example, nitrification (Keeney, 1986; Rolston, 1986).

\section{The isotope $\mathbf{N}$-labeled methods}

Denitrification activity can be determined using stable nitrogen isotopes in both laboratory incubations and in field measurements. With this approach, one or several 15N-labeled nitrogen compounds, such as $\mathrm{NO}_{3^{-}}$, ammonium, fertilizers, or plant litter, are added to the soil.

The subsequent production dinitrogen and $\mathrm{N}_{2} \mathrm{O}$ by denitrification is measured by quantifying the increase of $15 \mathrm{~N}$-labeled gases by mass spectrometry. As with the $\mathrm{C}_{2} \mathrm{H}_{2}$ inhibition method, closed chambers are used to estimate denitrification activity in the field (Nason and Myrold, 1991). This method is limited by the high cost of $15 \mathrm{~N}$ and the need to add nitrogen in the soil.

Methods based on the use of $13 \mathrm{~N}$ have also been described (Smith et al., 1978; Tiedje et al., 1979), but these cannot be applied in the field (Tiedje et al., 1989). 


\section{Resolving diversity of denitrifiers}

Over several decades, diversity of denitrifiers in soil was studied by isolating bacterial strains. Basically, dilutions of soil suspension were spread on various agar medium supplemented with $\mathrm{NO}_{3}$ - After incubation under anaerobic conditions, isolated colonies were characterized using phenotypic or metabolic tests, and later on by using molecular approaches (Cheneby et al., 2000, 2004; Garcia, 1977; Pichinoty et al., 1976). The most frequently used approaches today to target denitrifiers in soil start with extraction of nucleic acids (DNA or RNA) from the soil (Figure. 2).

The extracted nucleic acids are then purified and amplified by PCR using primers targeting the denitrifier community. In the late 1990s, the genes nirS and nirK encoding the key enzymes of the denitrification pathway were first used as molecular markers to describe the diversity of the denitrifier community (Braker et al., 1998; Hallin and Lindgren, 1999).

Amplification of extracted nucleic acids using primers targeting the denitrification genes is actually the most common way to analyze denitrifier communities (Bothe et al., 2000; Hallin et al., 2007).

\section{Quantification of identifiers}

Denitrifiers were first quantified by plating serial dilutions of soil suspension and counting true denitrifying isolates based on their ability to reduce $\mathrm{NO}_{3}$ - into gaseous nitrogen production. However, the most common way to count denitrifiers using a cultivation technique is to apply the most probable number (MPN) method (Volz, 1977).

Serial dilutions of soil suspension are inoculated into anaerobic replicates medium tubes amended with $\mathrm{NO}_{3}$ - and $\mathrm{C}_{2} \mathrm{H}_{2}$. Dilution tubes are then scored positive when $\mathrm{N}_{2} \mathrm{O}$ is detected, and results are then converted into cell numbers copy using the McCrady table.

\section{Results and Discussion}

\section{Important of denitrification in the nitrogen cycle}

Nitrogen $\left(\mathrm{N}_{2}\right)$ gas is the most abundant component of the atmosphere, accounting for nearly $79 \%$ of air volume.

As we will see, this extensive reservoir in the air is largely unavailable to most organisms. Only about $0.03 \%$ of the earth's nitrogen is combined (or fixed) in some other form such as nitrates $\left(\mathrm{NO}_{3^{-}}\right)$, nitrites $\left(\mathrm{NO}_{2}{ }^{-}\right)$, ammonium ion $\left(\mathrm{NH}_{4}+\right)$, and organic nitrogen compounds (proteins, nucleic acids).

The nitrogen cycleis relatively more intricate than other cycles because it involves such a diversity of specialized microbes to maintain the flow of the cycle, in many ways, it is actually more of a nitrogen "web" because of the array of adaptations that occur. Higher plants can utilize $\mathrm{NO}_{3}{ }^{-}$and $\mathrm{NH}_{4}+$ animals must receive nitrogen in organic form from plants or other animals; and microorganisms vary in their source, using $\mathrm{NO}_{2-}, \mathrm{NO}_{3}-, \mathrm{NH}_{4}+$, $\mathrm{N}_{2}$, and organic nitrogen. The cycle includes four basic types of reactions: nitrogen fixation, ammonification, nitrification, and denitrification.

The Nitrogen cycle is complete when nitrogen compounds are returned to the reservoir in the air by a reaction series that converts NO3through intermediate steps to atmospheric nitrogen, called denitrification. Bacteria such as Bacillus, Pseudomonas, Spirillum, and Thiobacilluscan carry out this denitrification process to completion (Foundations in Microbiology 4th Edition, 2001). 
Factors causing variations in denitrification

\section{Landscape-scale and field-scale factors}

At the landscape scale, it is useful to focus on soil type (texture, natural drainage capacity) as a controller of the variation in soil moisture and on plant community type as a controller of $\mathrm{C}$ and $\mathrm{NO}_{3}--\mathrm{N}$ availability to denitrifiers. Overall, rainfall is the main factor controlling denitrification, while other factors such as soil-available $\mathrm{C}$ and $\mathrm{N}$ are of less importance ( $\mathrm{Pu}, 1996)$.

As in temperate regions, denitrification in tropical/subtropical soils is strongly related to the nature and amount of soil $\mathrm{C}$ and $\mathrm{N}$ turnover when rainfall is not a limiting factor (Griffiths et al., 1993). Examination of fieldscale and landscape-scale controls of denitrification needs to focus on factors that influence $\mathrm{C}$ and $\mathrm{N}$ turnover such as land use types, crop types, residue management systems, organic matter inputs, nutrient management strategies, intercropping, and harvest intensity. Land use and management practices which can favor soil $\mathrm{C}$ and/or $\mathrm{N}$ accumulation and anaerobic microorganism activities enhance soil denitrification capacity.

\section{Temperature}

Soil temperature and soil water content are known factors that affect gaseous nitrogen losses and the $\mathrm{N}_{2} \mathrm{O} / \mathrm{N}_{2}$ ratio. Under constant laboratory conditions, this ratio increased exponentially with increasing soil temperature (Maag and Vinther, 1996).

\section{Presence of oxygen and water}

Soil oxygen concentrations below $5 \%$ resulted in denitrification being the main microbial respiratory process when $\mathrm{NO}_{3}$ - was available. In addition, at $10 \%$ oxygen concentration and moisture content between $40 \%$ and $60 \%$, denitrification was the main source of emitted $\mathrm{N}_{2} \mathrm{O}$. Water content depends on the pore structure of the soil, which in turn is affected by soil type, organic matter content, and land use. Bakken et al., (1987) demonstrated that the pore space structure appears to be the major factor explaining the difference in mean denitrification rates by comparing pasture and cropped soil.

\section{Rhizosphere of crop}

The rhizosphere is the volume of soil influenced by plant roots (Hiltner, 1904). The growth and activity of the root system induce significant modifications in the physicochemical and biological properties of the soil surrounding the roots, which correspond to the so-called rhizosphere effect. It is well known that the major factors regulating denitrification: carbon, oxygen, and $\mathrm{NO}_{3}$ - can be modified in the rhizosphere of plants. Thus, carbon compounds, which can be used as electron donor by denitrifiers, are released by plants roots in the surrounding soil through rhizodeposition. The effect of plants on oxygen and $\mathrm{NO}_{3}$ - concentration is more complex. Oxygen concentration can be lowered in the rhizosphere by respiration of the roots and microorganisms. On the other hand, consumption of water by plant roots increases soil gas exchange and oxygen concentration. Some plants, such as rice, also transport oxygen from the air down to the soil in water-saturated soil. Finally, when roots grow and penetrate the soil, they can modify soil compaction, which affects oxygen diffusion. Nitrate is used by both plants and microorganisms and the competition for $\mathrm{NO}_{3}$ is therefore high in the rhizosphere during the growing season. However, plants can also potentially provide $\mathrm{NO}_{3}$ - for denitrification when organic matter present in root exudates is mineralized. Moreover, during plant senescence and litter decomposition in fall and winter, nitrogen becomes bioavailable and can be denitrified. 


\section{Presence of fertilizers}

Research on denitrification in agricultural soil has mainly focused on effects of fertilizers. Not surprisingly, nitrogen fertilizers promote denitrification activity in agricultural soil and substantial amounts of fertilizer added nitrogenis lost through denitrification (De Klein and Van Logtestijn, 1994; Kaiser et al., 1998; Mulvaney et al., 1997). Fertilization can also affect the $\mathrm{N}_{2} \mathrm{O}$ to $\mathrm{N}_{2}$ ratio from denitrification, and $\mathrm{N}_{2} \mathrm{O}$ emissions are most likely increasing due to an increased input of fertilization (Skiba and Smith, 2000). It has often been suggested that denitrification is limited under field conditions by NO3availability (Bronson et al., 1992; Mahmood et al., 2005), which in turn is influenced by the fertilizer type and application rate together with timing and application method. For example, losses by denitrification are often highest shortly after fertilization application and these losses can account for 50-75\% of the annual loss in afield (Ellis et al., 1998; Mogge et al., 1999). The combination of high nitrogen application rates and poor soil drainage give rise to higher denitrification activity than lower application rates and good drainage (Hofstra and Bouwman, 2005).

\section{Soil pH}

Changes in $\mathrm{pH}$ can both directly and indirectly affected denitrification activity, and in general, denitrification is higher at neutral rather than acidic conditions (Bremner and Shaw, 1958; Simek and Cooper, 2002).

Fig.1 The denitrification cascade with the different reductases and name of the genes encoding the corresponding catalytic subunits (Laurent et al., 2007)

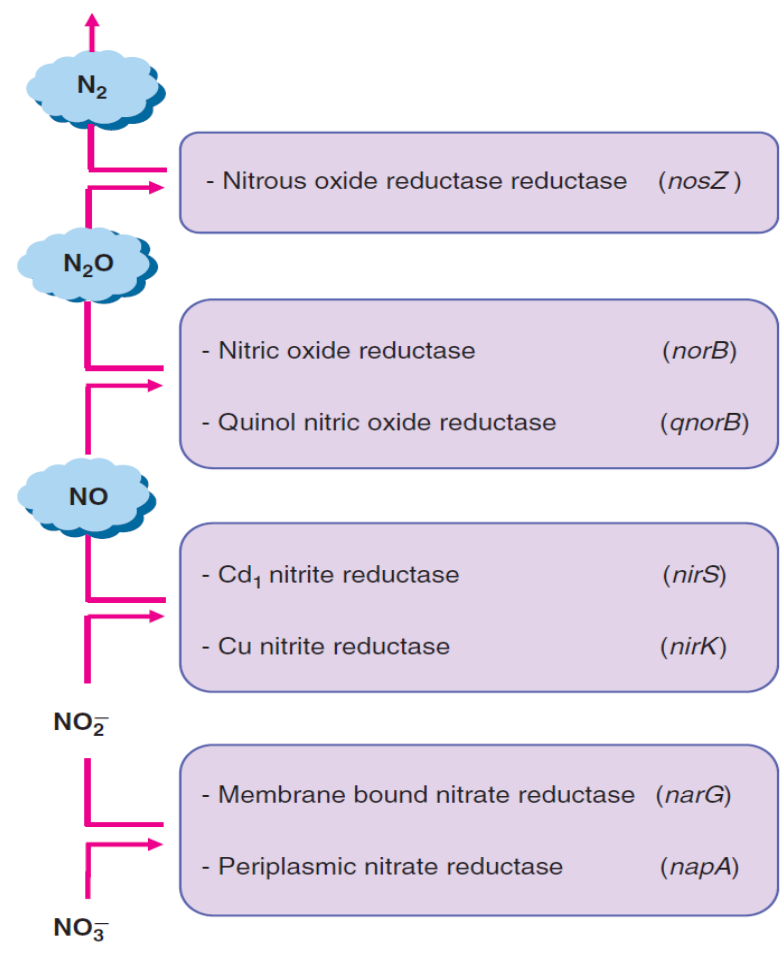


Fig.2 Methods used to assess diversity of denitrifies with a PCR-based approach (Laurent et al., 2007)
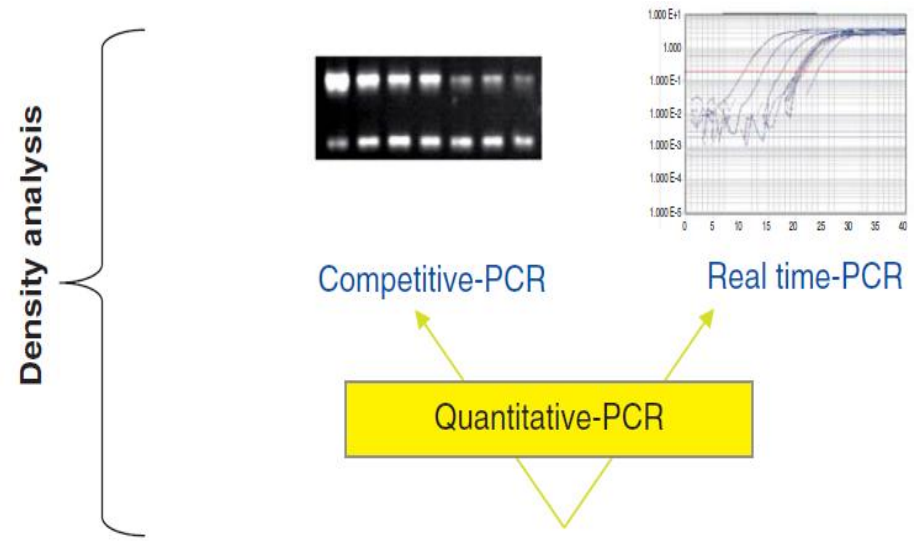

Competitive-PCR

Real time-PCR
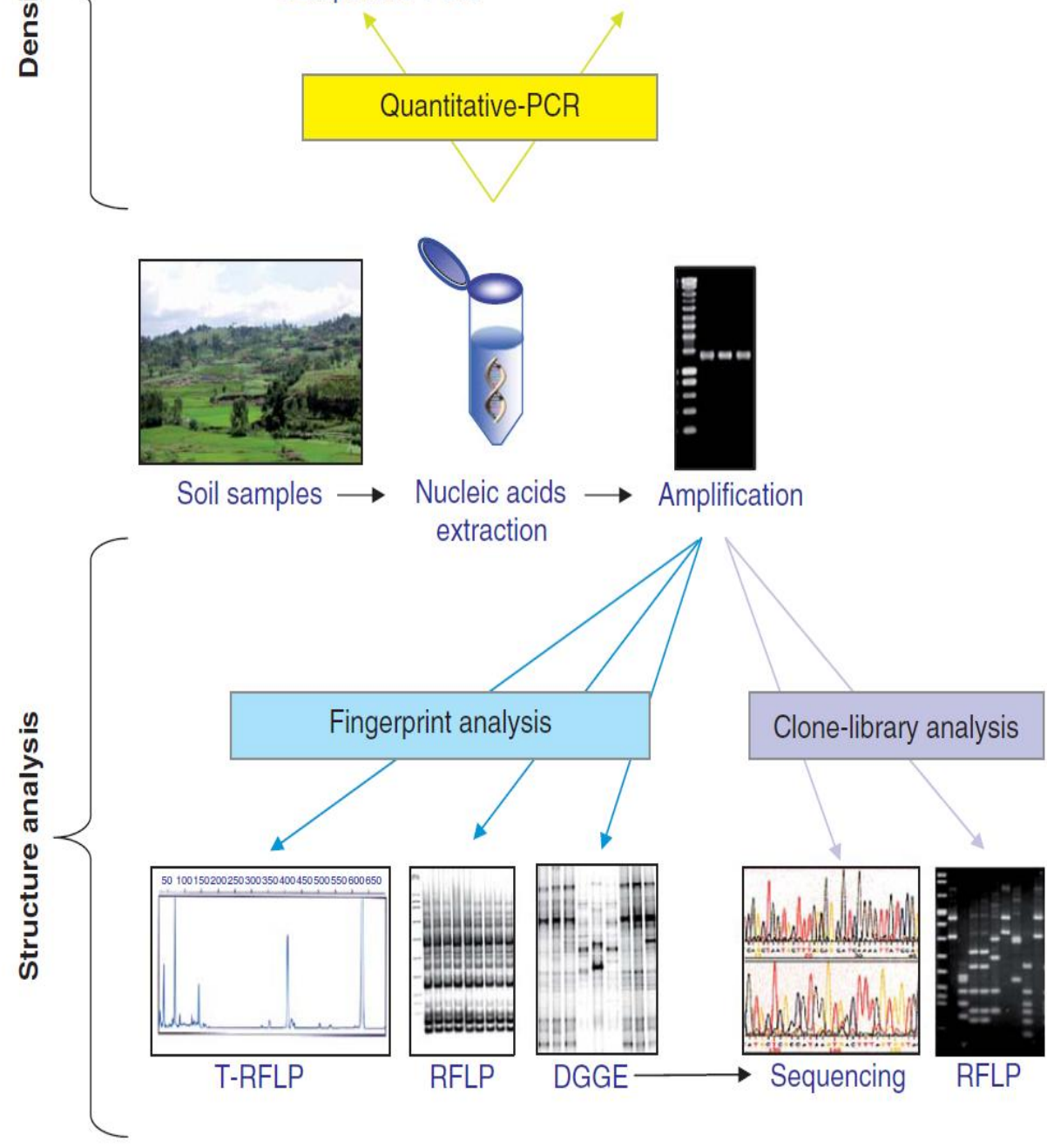

\section{Environmental pollution}

For agricultural soil, there is concern about responsible use and maintenance of microbial functions and diversity for sustainable ecosystem management and crop production. Several studies have shown that denitrification is inhibited by organic pollutants, for example, polyaromatic hydrocarbons (PAHs) (Richards and Knowles, 1995; Roy and Greer, 2000) and pesticides (Bollag and Kurek, 1980), in addition to heavy metals (Bardgett et al., 1994; Bollag and Barabasz, 1979). It is also known that the enzymes involved in the denitrification chain are differently affected by various stress factors, with $\mathrm{N}_{2} \mathrm{O}$ reductase being the most sensitive 
(Bonin et al., 1989; Firestone et al., 1980). Inhibition of this enzyme results in increased production of $\mathrm{N}_{2} \mathrm{O}$, and this has been shown to be the case in heavy metal contaminated soil (Roy and Greer, 2000).

In conclusion, with agricultural progress in less developed regions, over $60 \%$ of all $\mathrm{N}$ fertilizers will be used in the tropics and subtropics by 2020, increasing the emissions, transportation, and deposition of $\mathrm{N}$-containing compounds. There is increasing evidence that denitrification in tropical/subtropical soils may have some characteristics in comparison with those in temperate zones. However, the factors and mechanisms responsible for the differences in denitrification between tropical/subtropical and temperate soils warrant further study. This would deepen our knowledge about $\mathrm{N}$ cycle in tropical/subtropical soils under the environmental conditions. GCC has caused many physical, chemical, and biological changes in terrestrial ecosystems (e.g., elevated atmospheric $\mathrm{CO}_{2}$ and temperature, modifications of precipitation patterns, atmospheric $\mathrm{N}$ deposition, land use change, and forest fires/ biomass burning). GCC could lead to shifts in biogeochemical cycles of $\mathrm{N}$ which may conversely regulate ecosystem responses to environmental changes. Most studies of the consequences of $\mathrm{N}$ cycle alteration induced by environmental changes have been performed in

Temperate ecosystems in which biological processes are limited by $\mathrm{N}$ supply, however, the mechanisms involved in the biogeochemical regulation of tropical and subtropical ecosystem responses to the environmental changes are largely unknown, particularly in terms of the relationship between GCC and biogeochemical cycles of $\mathrm{N}$ and nutrients. Therefore, we advance some hypotheses on the potential coupling process and mechanisms between denitrification and GCC through biogeochemical cycles of $\mathrm{C}$ and nutrients.

The $\mathrm{C}$ biogeochemical cycling is a key coupling point between terrestrial ecosystems and the climate system. Some studies have shown that the $\mathrm{N}$ biogeochemical cycling is further driven or limited by $\mathrm{C}$ and nutrient availability. It is worth pointing out that the hydrological cycle is also a key ecosystem process which drives the $\mathrm{C}$ and nutrient cycles and denitrification dynamics under global warming and, therefore, needs to be considered when we study the previously mentioned issues. Furthermore, to study the impacts of environmental changes on $\mathrm{N}$ cycle and evaluate the role of $\mathrm{N}$ cycle in regulating ecosystem responses to environmental changes, it should place $\mathrm{N}$ cycle into the context of the interactions of $\mathrm{C}, \mathrm{N}$, and $\mathrm{P}$ biogeochemical cycles and use multiple disciplinary approaches, including soil chemistry, microbial ecology, plant physiology, and molecular biology. Such information would provide a better understanding of the relationships and relative importance of denitrification in comparison with these processes.

\section{Acknowledgement}

The overall implementation of this study including literature collection and manuscript preparation were done by Praveen Solanki, Maitreyie Narayan, Hina Khatoon, Shiv Singh Meena and Lakshmi Tewari. Praveen Solanki and Maitreyie Narayan critically reviewed the article. All authors read and approved the final manuscript.

\section{References}

Aulakh, M.S., Doran, J.W. and Mosier, A.R. 1992. Soil denitrification significance, measurement, and effects of management. In: Stewart BA (ed) Adva. in Soil Sci., 18. Springer, New York.

Aulakh, M.S., Khera, T.S., Doran, J.W. and Bronson, K.F. 2001.Managing crop residue with green manure, urea, and tillage in a rice-wheat rotation. Soil Sci. Soc. Am. J. 65: 820-827.

Balderston, W.L., Sherr, B. and Payne, W.J. 1976. Blockage by acetylene of nitrous oxide reduction in Pseudomonas 
perfectomarinus. Appl. Environ. Microbiol. 31: 504-508.

Boyer, E.W., Alexander, R.B., Parton, W.J., Li, C., Butterbach-Bahl K., Donner, S.D., Skaggs, R.W., Del, Grosso S.J. 2006. Modelingdenitrification in terrestrial and aquatic ecosystems at regional scales. Ecol Appl. 16: 2123-2142.

Cheneby, D., Philippot, L., Hartmann, A. andGermon, J.C. 2000. 16S rDNA analysis for the characterization of denitrifying bacteria isolates from three agricultural soils. Microbiol. Ecol. 34: 121-128.

Clays-Josserand, A., Lemanceau, P., Philippot, L. and Lensi, R. 1995. Influence of two plant species (flax and tomato) on the distribution of nitrogen dissimilative abilities within fluorescent Pseudomonas spp. Appl. Environ. Microbiol. 61: 17451749.

Conrad, R. 1996. Soil microorganisms as controllers of atmospheric trace gases $\left(\mathrm{H}_{2}, \mathrm{CO}, \mathrm{CH}_{4}, \mathrm{OCS}, \mathrm{N}_{2} \mathrm{O}\right.$, and $\left.\mathrm{NO}\right)$. Microbiol. Reviews. 60: 609-640.

Daniel, R.M., Limmer, A.W., Steele, K.W. and Smith, I.M. 1982. Anaerobic growth, nitrate reduction and denitrification in 46 Rhizobium strains. J. Gen. Microbiol., 128: 1811-1815.

Daniel, R.M., Smith, I.M., Philipp, A.D., Ratcliffe, H.D., Drozd, J. W. and Bull, A.T. 1980. Anaerobic growth and denitrification by Rhizobium japonicum and other rhizobia. J. Gen. Microbiol. 120: $517-521$.

Dannenmann, M., Butterbach-Bahl, K., Gasche, R., Willibald, G. and Papen, H. 2008.Dinitrogen emissions and the $\mathrm{N} 2: \mathrm{N} 2 \mathrm{O}$ emission ratio of a RendzicLeptosol as influenced by $\mathrm{pH}$ and forest thinning. Soil Biol. Biochem. 40: 2317-2323.

Foundations in Microbiology, 4th Edition. 2001. Kathleen Park Talaroand Arthur Talaro. ISBN: 0-07-248864-6.

Galloway, J.N., Dentener, D.G., Capone, E.W., Boyer, E.W., Howarth, R.W., Seitzinger, S.P., Asner, G.P., Cleveland, C.C., Green,
P.A., Holland, E.A., Karl, D.M., Michaels, A.F., Porter, J.H., Townsend, A.R., Vorosmarty, C.J. 2004. Nitrogen cycles: past, present and future. Biogeochem., 70: 153-226.

Galloway, J.N., Townsend, A.R., Erisman, J.W., Bekunda, M., Cai, Z.C., Freney, J.R., Martinelli, L.A., Seitzinger, S.P. and Sutton, M.A. 2008. Transformation of the nitrogen cycle: recent trends, questions, and potential solutions. Sci., 320: 889892.

Giles, J. 2005. Fallout of fertilizers set too low, studies warn. Nature, 434, 262.

Griffiths, R.P., Caldwell, B.A. andSollins, P. 1993. Effects of vegetation regime on denitrification potential in two tropical volcanic soils. Biol. Fertil Soils. 16:157162.

Henry, S., Baudoin, E., Lopez-Gutierrez, J.C., Martin-Laurent, F., Brauman, A. and Philippot, L. 2004. Quantification of denitrifying bacteria in soils by nirK gene targeted real-time PCR. J. Microbiol. Methods 59, 327-335.

Henry, S., Bru, D., Stres, B., Hallet, S. and Philippot, L. 2006.Quantitative deduction of the nosZ gene, encoding nitrous oxide reductase, and comparison of the abundance of $16 \mathrm{~S}$ rRNA, narG, nirK, and nosZ genes in soils. Appl. Environ. Microbiol. 72: 5181-5189.

Hofstra, N. and Bouwman, A.F. 2005.Denitrification in agricultural soils: summarizing published data and estimating global annual rates. Nutr. $\mathrm{Cycl}$ Agroecosys. 72: 267-278.

Houghton, J.T., Fiho, L. G.M., Bonduki, Y., Griggs, D.J. and Callender, B.A. 1996. 1996 IPCC guidelines for national greenhouse gas inventories, Cambridge University Press.

Keeney, R.D. 1986. Critique of the acetylene blockage technique for field measurement of denitrification. In "Field Measurement of Dinitrogen Fixation and Denitrification' (R. D. Hauck and E. W. Weaver, Eds.), pp. 103-115. Madison, 
Wisconsin, USA, Soil Science Society of Amercia.

Kralova, M. 1991. Effect of redox potentials on denitrification in soil. Sci. Agric. Biochem., 23:101-106.

Laurent, P., Sara, H. and Michael, S. 2007. Ecology of Denitrifying Prokaryotes in Agricultural Soil. Advances in Agronomy, 96. DOI: 10.1016/S0065-2113(07)960034.

Maag, M. and Vinther, F.P. 1999. Effect of temperature and water on gaseous emissions from soils treated with animal slurry. Soil Sci. Soc. Am. J. 63: 858-865.

Mahmood, T., Ali, R., Malik, K.A., Aslam, Z. and Ali, S. 2005. Seasonal pattern of denitrification under an irrigated wheatmaize cropping system fertilized with urea and farmyard manure in different combinations. Biol. Fertil. Soils. 42:1-9.

Mahmood, T., Ali, R., Sajjad, M.I., Chaudhri, M.B., Tahir, G.R., Azam, F. 2000.Denitrification and total fertilizer-N losses from an irrigated cotton field. Biol. Fertil. Soils, 31: 270-278.

Mahne, I. and Tiedje, J.M. 1995. Criteria and methodology for identifying respiratory denitrifiers. Appl. Environ. Microbiol., 61(3): 1110-1115.

Mosier, A.R., Duxbury, J.M., Freney, J.R., Heinemeyer, O. and Minami, K. 1998. Assessing and mitigating $\mathrm{N} 2 \mathrm{O}$ emissions from agricultural soils. Climatic Change, 40: 7-38.

Nason, G.E. and Myrold, D.D. 1991. 15N in soil research: Appropriate application of rate estimation procedures. Agr. Eco. Env. 34: 1-4.

O'Hara, G.W. and Daniel, R.M. 1985. Rhizobial denitrification: A review. Soil Biol. Biochem., 17: 1-9.

Philippot, L. 2005. Denitrification in pathogenic bacteria: For better or worst? Trends in Microbiol., 13: 191-192.

$\mathrm{Pu}$, G.X. 1996. Denitrification in cereal and sugarcane soils of Australia.Ph.D. thesis, Griffith University, Queensland, Australia $\mathrm{Pu}$ GX, Saffigna PG, Xu ZH (2001) Denitrification, leaching and immobilization of $15 \mathrm{~N}$-labelled nitrate in winter under windrowed harvesting residues in hoop pine plantations of 1-3 years old in subtropical Australia. For. Ecol. Manage. 152:183-194.

Pu, G.X., Xu, Z.H, Saffigna, P.G. 2002. Fate of $15 \mathrm{~N}$-labelled nitrate in a wet summer under different residue management regimes in young hoop pine plantations. For. Ecol. Manage., 170: 285-298.

Revsbech, N.P., Cedhagen, T., et al., 2006. Evidence for complete denitrification in a benthic foraminifer. Nature, 443: 93-96.

Risgaard-Petersen, N., Langezaal, A.M., Ingvardsen, S., Schmid, M.C., Jetten, M.S., Op den Camp, H.J., Derksen, J.W., Pina-Ochoa, E., Eriksson, S.P., Nielsen, L.P., Rolston, D.E. 1986. Limitation of the acetylene-blockage technique for field measurement of denitrification. In "Field Measurement of Dinitrogen Fixation and Denitrification" (R. D. Hauck and E. W. Weaver, Eds.), pp. 193-201. Soil Science Society of America, Madison, Wisconsin, USA.

Ryden, J.C. and Dawson, K.P. 1982. Evaluation of the acetylene-inhibition technique for the measurement of denitrification in grassland soils. J. Sci. Food. Agric., 33: 1197-1206.

Ryden, J.C., Skinner, J.H. and Nixon, D.J. 1987. Soil core incubation system for the field measurement of denitrification using acetylene-inhibition. Soil Biol. Biochem. 19: 753-757.

Shaw, L.J., Nicol, G.W., Smith, Z., Fear, J., Prosser, J.I. and Baggs, E.M. 2006. Nitrosospira spp. can produce nitrous oxide via a nitrifier denitrification pathway. Envi. Microbiol. 8: 214-222.

Simek, M., Cooper, J.E., Picek, T. and Santruckova, H. 2000.Denitrification in arable soils in relation to their physicochemical properties and fertilization practice. Soil Biol. Biochem., 32:101-110.

Simek, M. and Cooper, J.E. 2002. The influence of soil $\mathrm{pH}$ on denitrification: progress towards the understanding of this 
interaction over the last 50 years. Eur. J. Soil Sci. 53:345-354.

Skiba, U., Smith, K.A. and Fowler, D. 1993. Nitrification and denitrification as sources of nitric oxide and nitrous oxide in a sandy loam soil. Soil Biol. Biochem., 25: 1527-1536.

Smith, M.S., Firestone, M.K. and Tiedje, J.M. 1978. The acetylene method for short term measurement of soil denitrification and its evaluation using nitrogen-13. Soil Sci. Soc. Am. J., 42: 611-615.

Stevens, R.J. and Laughlin, R.J. 1998. Measurement of nitrous oxide and dinitrogen emissions from agricultural soils. Nutr. Cyc. Agro. 52: 131-139.

Stouthamer, A.H. 1988. Dissimilatory reduction of oxidized nitrogen compounds. In "Biology of Anaerobic Microorganisms", (A. J. B. Zehnder, Ed.).Marcel Dekker, Inc., New York.

Tiedje, J.M. 1988. Ecology of denitrification and dissimilatory nitrate reduction to ammonium. In "Biology of Anaerobic Microorganisms"' (A. J. B. Zehnder, Ed.), pp. 179-244. John Wiley and Sons; Inc, New York.

Tiedje, J.M. 1988. Ecology of denitrification and dissimilatory nitrate reduction to ammonium. In "Biology of Anaerobic Microorganisms" (A. J. B. Zehnder, Ed.), pp. 179-244. John Wiley and Sons; Inc, New York.
Tiedje, J.M., Firestone, R.B., Firestone, M.K., Betlach, M.R., Smith, M.S. and Caskey, W. 1979.Methods for the production and use of Nitroge-13 in studies of denitrification. Soil Sci. Soc. Am. J., 43: 709-716.

Tiedje, J.M., Simkins, S. and Groffman, P.M. 1989. Perspectives on measurement of denitrification in the field including recommended protocols for acetylenebased methods. Plant Soil, 115: 261-284.

Tilman, D., Cassman, K.G., Matson, P.A., Naylor, R. and Polasky, S. 2002. Agricultural sustainability and intensive production practices. Nature, 418: 671673.

Treush, A.H., Leininger, S., Kletzin, A., Schuster, S.C., Klenk, H.P. and Schleper, C. 2005. Novel genes for nitrite reductase and Amo-related proteins indicate a role of uncultivated mesophiliccrenarchaeota in nitrogen cycling. Environ. Microbiol., 7: 1985-1995.

Wijler, J. and Delwiche, C.C. 1954. Investigations on the denitrifying process in soil. Plant Soil, 5:155-169.

Yoshinari, T., Hynes, R. and Knowles, R. 1977.Acetylene inhibition of nitrous oxide reduction and measurement of denitrification and nitrogen fixation in soil. Soil. Biol. Biochem., 9: 177-183.

Zumft, W.G. 1997. Cell biology and molecular basis of denitrification. Microbiol Mol. Biol. R., 61: 533-616.

\section{How to cite this article:}

Praveen Solanki, Shiv Singh Meena, Maitreyie Narayan, Hina Khatoon and Lakshmi Tewari. 2017. Denitrification Process as an Indicator of Soil Health. Int.J.Curr.Microbiol.App.Sci. 6(5): 26452657. doi: https://doi.org/10.20546/ijcmas.2017.605.296 